\title{
PENGARUH SISTEM PENGEMBANGAN SUMBER DAYA MANUSIA TERHADAP KINERJA KARYAWAN DI PT. ARTA SEDANA SINGARAJA
}

\author{
M.W.D. Purnama', P.I. Rahmawati ${ }^{2}$, N.N. Yulianthini ${ }^{3}$ \\ 1,2,3 Jurusan Manajemen, Universitas Pendidikan Ganesha, Singaraja. \\ e-mail: wulandwipurnama1@gmail.com, putuindah@yahoo.co.id, nyoman.yulianthini@undiksha.ac.id
}

\begin{abstract}
Abstrak
Penelitian ini bertujuan untuk mengetahui (1) sistem pengembangan sumber daya manusia di PT. Arta Sedana Singaraja (2) pengaruh sistem pengembangan sumber daya manusia terhadap kinerja karyawan di PT. Arta Sedana Singaraja. Penelitian ini menggunakan jenis penelitian kuantitatif dengan metode analisis regresi linier sederhana. Populasi penelitian ini berjumlah 35 orang. Pengumpulan data dilakukan dengan metode kuesioner dan wawancara. Hasil penelitian ini menunjukkan bahwa (1) terdapat empat sistem pengembangan sumber daya manusia yaitu pelatihan selling skill dan training supervisory skill, promosi jabatan untuk sales menjadi supervisor sales, fasilitas handphone yang memiliki sistem sales force automation, pemberian isentif terhadap karyawan yang melampaui target; (2) sistem pengembangan sumber daya manusia berpengaruh positif dan signifikan terhadap kinerja karyawan di PT. Arta Sedana Singaraja sebesar $65,8 \%$.
\end{abstract}

Kata kunci: kinerja karyawan, pelatihan, sistem pengembangan sumber daya manusia

\begin{abstract}
This study aimed to find out the human resource development at PT. Arta Sedana Singaraja and the effect of the human resource development system on the performance of employees at PT. Arta Sedana Singaraja. The reasearch used quantitative research using simple linear regression analysis method. The population of this research were 35 people. The data collection was carried out using questionnaire and interview. The results of this study showed that (1) there were four human resource development systems that is, selling skills training and supervisory skills training, promotion of positions from sales to supervisor sales, mobile facilities that have a sales force automation system, giving incentives to employees who exceed the target; (2) the human resource development system partially has a positive and significant effect on the performance of employees at PT. Arta Sedana Singaraja by $65.8 \%$.
\end{abstract}

Keywords:human resource development system, training, promotion, and employee performance.

\section{PENDAHULUAN}

Suatu organisasi pasti menginginkan hasil kerja yang baik dalam kurun waktu tertentu, untuk mencapai hasil tersebut maka diperlukan sumber daya manusia yang berkualitas. Hal ini menyebabkan semua perusahaan dituntut untuk memperoleh, mengembangkan dan mempertahankan sumber daya manusia yang berkualitas. Perusahaan percaya jika karyawaan memiliki kualitas tinggi maka hasil pekerjaannya akan berkualitas pula. Pernyataan tersebut dipertegas oleh Gorda (2004) bahwa keberhasilan suatu perusahaan hanya dapat dicapai dengan upaya dan kualitas sumber daya manusia (SDM) yang dimilikinya. Semakin baik kualitas sumber daya manusia yang dimiliki maka akan semakin baik hasil yang dicapai. Sebaliknya semakin rendah kualitas sumber daya manusianya maka akan semakin rendah pula hasil yang dicapai, itu terjadi karena bagaimanapun canggihnya sarana dan prasarana yang dimiliki oleh suatu perusahaan jika tidak didukung oleh sumber daya manusia yang berkualitas akan menghambat tercapainya tujuan perusahaan.

PT. Arta Sedana Singaraja merupakan perusahaan yang bergerak di bidang distribusi yang beralamat di Jalan Pulau Komodo, Banyuning, Kecamatan Buleleng. Jenis layanan yang diberikan di PT. Arta Sedana yaitu melayani penjualan dan pendistribusian barang kepada konsumen. Distribusi barang dapat melalui perantara pos atau langsung mendatangi konsumen ataupun konsumen langsung datang ke kantor. PT. Arta Sedana juga 
melayani penjualan dalam jumlah besar untuk para pedagang pengecer dan para pedagang besar (Grosir). Rute sales dan driver pada setiap harinya di bagi menjadi 3 yaitu perjalanan timur, barat, dan tengah. Berdasarkan kondisi di lapangan pada saat melakukan observasi dan wawancara di PT. Arta Sedana Singaraja menunjukkan bahwa kinerja pegawai masih belum optimal. Pada karyawan belum mampu menyelesaikan targetnya dalam melakukan penjualan barang ke outlet, terjadinya keterlambatan pengiriman berang kepada konsumen. Para karyawan belum mampu mandiri dalam melaksanakan pekerjannya.

Pengembangan sumber daya manusia dianggap salah satu cara yang paling efektif dalam meningkatkan kinerja hal ini di pertegas oleh Mathis dan Jackson (2010) yang menyatakan bahwa salah satu faktor yang mempengaruhi kinerja adalah sistem pengembangan sumber daya manusia. Jika sistem pengembangan sumber daya manusia terlaksana dengan baik maka kualitas dari karyawan akan meningkat, dengan meningkatnya kualitas karyawan maka kinerja karyawan akan meningkat pula. Perusahaan akan dapat berjalan dengan baik bila organisasi tersebut memiliki kemampuan sumber daya manusia yang baik dalam pencapaian tujuan organisasi yang telah ditetapkan untuk itu diperlukan sistem pengembangan sumber daya manusia bagi karyawan agar mereka dapat memahami teknologi yang diperlukan sehingga dapat menambah pengetahuan dan keterampilan karyawan.

Berdasarkan pengamatan dan wawancara di PT. Arta Sedana Singaraja telah melaksanakan sistem pengembangan dalam rangka membantu menunjang karir karyawan, contoh nyata sistem pengembangan karyawan yang sudah dilakukan di PT. Arta Sedana Singaraja adalah mempromosikan sales yang berkompeten ke supervisor sales. Dukungan perusahaan yaitu memfasilitasi sales dengan handphone yang memiliki sistem sales force automation jadi sales tidak perlu bingung untuk menginput order tentunya di pihak administrasi juga lebih mudah dalam bekerja dan pihak gudang lebih cepat dalam mempersiapkan barang yang akan di kirim ke outlet selain itu pihak management juga bisa mengontrol kesungguhan karyawan dalam bekerja. PT. Arta Sedana akan memberikan isentif kepada karyawan yang mencapat target. Pelatihan dilaksanakan sesuai dengan kebutuhan dan keahlian yang dibutuhkan dalam perusahan serta sesuai dengan pendidikan dan pelatihan berdasarkan jenis pekerja karyawan. Pendidikan dan pelatihan yang mengarahkan pada peningkatan profesionalisme kinerja karyawan diantaranya mengadakan pelatihan selling skill dan supervisory skill. Tujuan diadakan pendidikan dan pelatihan ini yaitu agar para karyawan dapat memperdalam keterampilan dan kemampuan sesuai dengan bidang yang dikerjakan.

Sistem pengembangan sumber daya manusia harus dilaksanakan seefisien mungkin agar dapat benar-benar berperan dalam peningkatan kinerja karyawan, namun di dalam pelaksanaannya seringkali terjadi ketidaksesuaian penempatan karyawan dengan kemampuan yang dimiliki terhadap pekerjaan yang akan dikerjakannya sehingga dari masalah tersebut maka yang harus dilakukan perusahaan adalah melakukan pengembangan sumber daya manusia secara maksimal. Hal ini dipertegas Sedarmayanti (2009) mengemukakan bahwa sistem pengembangan sumber daya manusia dimaksudkan sebagai aktivitas yang perlu dilakukan oleh organisasi agar pengetahuan, kemampuan dan keahlian karyawan sesuai dengan tuntutan pekerjaan yang mereka lakukan dengan tujuan agar mampu mencapai kinerja yang diharapkan organisasi.

Berdasarkan sistem pengembangan yang telah dilaksanakan oleh PT. Arta Sedana Singaraja terjadi masalah yang menghambat tercapai kinerjanya secara optimal yaitu masih banyaknya karyawan yang bekerja dalam zona nyaman sehingga karyawan tidak berusaha mengembangakan kemampuan yang dimilikinya. Pada saat pelatihan, karyawan tidak berkonsentrasi mengikuti pelatihan yang diadakan perusahaan dan banyak karyawan yang sering absen untuk mengikuti pelatihan. Kurang maksimalnya dukungan perusahaan yang berikan kepada karyawan di bagian sales yaitu hanya memberikan handphone yang terdapat aplikasi sales force automation (SFA) namun tidak memberikan uang transport yang diberikan hanya gaji pokok. Promosi jabatan yang dilakukan belum transparan dan 
menyeluruh karena posisi jabatan di PT. Arta Sedana Singaraja sebagian besar yang diperlukan hanyalah sales dan untuk supervisor sales diperlukan 2 atau 3 orang di setiap cabangnya.

Tujuan dari penelitian ini adalah untuk mengetahui hal-hal sebagai berikut. (1) Sisten pengembangan sumber daya manusia di PT. Arta Sedana Singaraja. 2) Pengaruh sistem pengembangan sumber daya manusia terhadap kinerja karyawan di PT. Arta Sedana Singaraja. Adapun hasil dari penelitian ini diharapkan dapat memberi kontribusi bagi penerapan ilmu ekonomi khususnya di bidang Manajemen Sumber Daya Manusia, dan penelitian ini diharapkan dapat digunakan sebagai bahan referensi bagi penelitian selanjutnya. Secara teoritis hasil dari penelitian ini diharapkan dapat memberikan bahan yang bermanfaat sebagai pengembangan ilmu ekonomi pada bidang manajemen sumber daya manusia. Secara praktis penelitian ini diharapkan dapat memberikan kontribusi kepada pihak PT. Arta Sedana Singaraja untuk mengetahui sejauh mana sistem pengembangan sumber daya manusia berpengaruh terhadap kinerja karyawan serta dapat menjadi pertimbangan perusahaan dalam menyusun strategi untuk meningkatkan kinerja karyawan.

\section{KAJIAN PUSTAKA DAN PERUMUSAN HIPOTESIS Hubungan Sistem Pengembangan Sumber Daya Manusia terhadap Kinerja Karyawan}

Berdasarkan kenyataan bahwa seorang karyawan akan membutuhkan serangkaian pengetahuan, keahlian dan kemampuan yang berkembang untuk bekerja dengan baik dan suksesi posisi yang ditemui selama karirnya, maka pengembangan sumber daya manusia merupakan hal yang penting dilakukan untuk merubah sumber daya manusia yang dimiliki organisasi, dari suatu keadaan ke keadaan lain yang lebih baik melalui pendidikan jangka panjang dan pengalaman belajar dalam mempersiapkan pegawai untuk tanggung jawab di masa mendatang. Karyawan diharapkan mampu meningkatkan kinerjanya jika karyawan mampu memaksimalkan kegiatan pengembangan. Hal ini berkaitan dengan pernyataan Robert dan Jackson (2002) jika karyawan mengambil lebih banyak aktivitas pengembangan sumber daya manusia maka kinerja akan lebih tinggi lagi.

Pengembangan sumber daya manusia dapat dikatakan sebagai faktor utama meningkatnya kinerja karyawan karena karyawan yang memiliki pemahaman yang tinggi terhadap jabatannya setelah mengikuti pengembangan sumber daya manusia akan lebih mudah dalam menyelesaikan pekerjannya. Pernyataan tersebut dipertegas oleh teori Mathis dan Jackson (2010) yang menyatakan bahwa salah satu faktor yang mempengaruhi kinerja adalah sistem pengembangan sumber daya manusia. Pendapat lainnya menurut Chris Rowley dan Keith Jackson (2012) yaitu sistem pengembangan sumber daya manusia adalah sebuah proses yang dilakukan untuk mengembangkan pengetahuan, keahlian, dan kemampuan pekerja, demikian juga dengan kompetensi-kompetensi yang dikembangkan melalui pelatihan dan pengembangan untuk kepentingan peningkatan kinerja. Melakukan pengembangan sumber daya manusia secara maksimal akan dapat meningkatkan kinerja karyawan sehingga tujuan atau harapan perusahaan dapat tercapai.

Hubungan sistem pengembangan sumber daya manusia terhadap kinerja karyawan didukung pula dari hasil penelitian Dinny (2018), pengaruh sistem pengembangan sumber daya manusia terhadap kinerja karyawan PT Indofood Cbp Sukses Makmur Tbk Bitung dengan hasil penelitian menyatakan bahwa sistem pengembangan sumber daya manusia berpengaruh positif dan signifikan terhadap kinerja karyawan, sehingga jika sistem pengembangan sumber manusia dilakukan dengan maksimal maka kinerja dari karyawan akan mengalami peningkatan. Berdasarkan hasil penelitian yang telah dilakukan maka dapat ditarik hipotesis sebagai berikut.

$\mathrm{H} 1$ : Ada pengaruh sistem pengembangan sumber daya manusia terhadap kinerja karyawan

Kerangka berpikir adalah argumentasi dalam merumuskan hipotesis yang merupakan jawaban yang bersifat sementara dengan masalah yang diajukan. Kerangka berpikir menggambar-kan pengaruh antara variabel bebas terhadap variabel terikat yaitu pengaruh sistem pengembangan sumber daya manusia terhadap kinerja karyawan di PT. Arta Sedana Singaraja.Keberhasilan suau organisasi dapat dicerminkan melalui bagaimana kinerja 
karyawan yang ada pada perusahaan tersebut.Mangkunegara (2015) kinerja karyawan adalah hasil kerja secara kualitas dan kuantitas yang dicapai oleh seseorang karyawan dalam melaksanakan tugasnya sesuai dengan tanggung jawab yang diberikan kepadanya. Adapun indikator kinerja karyawan yang digunakan dalam penelitian menurut Robbins (2006) yaitu: (1) kualitas, (2) kuantitas, (3) ketepatan waktu, (4) efektivitas, (5) kemandirian.

Menurut Hasibuan (2011) sistem pengembangan sumber daya manusia adalah suatu kegiatan untuk meningkat-kan kemampuan teknis, teoritis, konseptual, dan moral karyawan sesuai dengan kebutuhan pekerjaannya/ jabatannya melalui pendidikan dan pelatihan. Adapun indikator yang digunakan dalam penelitian ini menurut Rivai (2003) yaitu: (1) kebutuhan karier, (2) dukungan perusahaan dalam bentuk moril, (3) dukungan perusahaan dalam bentuk materi, (4) pelatihan, (5) perlakuan adil dalam berkarier, (6) informasi karier, (7) promosi. Adapun kerangka pemikiran nampak pada Gambar 1

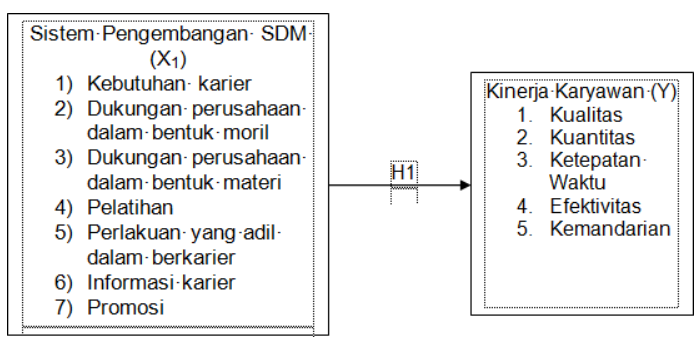

\section{Gambar 1}

\section{Kerangka Pemikiran}

Berdasarkan kajian teori dan kerangka pemikiran, dapat dirumuskan hipotesis penelitian yaitu ada pengaruh sistem pengembangan sumber daya manusia terhadap kinerja karyawan PT. Arta Sedana Singaraja.

\section{METODE}

Jenis penelitian yang digunakan adalah penelitian kuantitatif. Desain penelitian yang digunakan dalam penelitian ini adalah desain penelitian kausal. "Desain kausal ini digunakan untuk mengkaji hubungan sebab akibat antara variabel yang mempengaruhi dan variabel yang dipengaruhi" (Sugiyono, 2014: 56). Tahapan dalam desain penelitian kuantitatif kausal terdiri dari (1) merumuskan masalah, (2) mengkaji teori, (3) merumuskan hipotesis, (4) mengumpulkan data, (5) mengolah data, dan (6) menarik kesimpulan.

Penelitian ini dilakukan untuk mengetahui sistem pengembangan sumber daya manusia di PT. Arta Sedana Singaraja dan Pengaruh sistem pengembangan sumber daya manusia terhadap kinerja karyawan di PT. Arta Sedana Singaraja. Variabel bebas (independent) yang digunakan dalam penelitian ini yaitu sistem pengembangan sumber daya manusia $(X)$ sedangkan variabel terikat (dependent) yang digunakan adalah kinerja karyawan (Y).

Subjek dalam penelitian ini adalah seluruh karyawan PT. Arta Sedana Singaraja yang berjumlah 35 orang. Objek penelitian ini adalah sistem pengembangan sumber daya manusia $(\mathrm{X})$, dan kinerja karyawan $(\mathrm{Y})$.

Teknik pengumpulan data yang digunakan pada penelitian ini yaitu kuesioner dan wawancara. Salah satu skala yang umum dipakai dalam penyusunan kuesioner adalah Skala Likert, yaitu skala yang berisi lima tingkat jawaban yang disusun dalam bentuk suatu pernyataan dan diikuti oleh lima respon yang menunjukan tingkatan. Metode analisis yang digunakan dalam penelitian ini adalah analisis regresi linier sederhana. Analisis ini digunakan untuk mengetahui ada tidaknya pengaruh yang signifikan antara satu variabel independen dengan satu variabel dependen. Persamaan regresi untuk regresi linier sederhana Priyatno (2018:204) adalah sebagai berikut

$$
Y=\alpha+\beta X+\varepsilon
$$




\section{Dimana:}

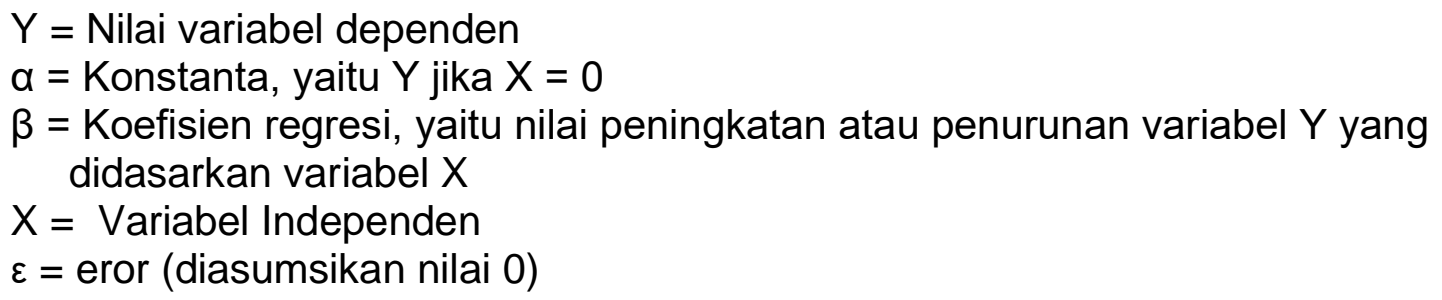

\section{HASIL DAN PEMBAHASAN} Hasil

\section{Sistem Pengembangan Sumber Daya Manusia di PT. Arta Sedana Singaraja}

Berdasarkan hasil observasi dan wawancara PT. Arta Sedana Singaraja menerapkan empat sistem pengembangan sumber daya manusia yaitu (1) diberikannya pelatihan selling skill dan training supervisory skill; (2) promosi jabatan untuk sales menjadi supervisor sales; (3) fasilitas handphone kepada sales yang memiliki sistem sales force automation (SFA); (4) Pemberian isentif bagi karyawan yang mencapai target. Berikut merupakan penjelasan hasil penelitian empat sistem pengembangan sumber manusia di PT. Arta Sedana Singaraja. Sistem pengembangan sumber daya manusia yang pertama yaitu pelatihan selling skill terhadap karyawan baru yang akan menduduki jabatan sales ini bertujuan untuk membekali para sales tentang pengetahuan dasar dan teknik melakukan penjualan terhadap konsumen kemudian memberikan motivasi untuk meningkatkan rasa percaya diri sehingga mampu berkomunikasi dengan semua orang secara tepat dan efektif serta mampu melakukan penjualan sesuai dengan target yang telah ditetapkan perusahaan. Instruktur dari kegiatan pelatihan ini telah memiliki kualifikasi pendidikan S2 dibagian marketing dan sudah memahami tentang bagaimana melatih seorang karyawan agar memiliki skill menjual suatu barang dengan membuat konsumen menjadi loyal. Pelatihan ini menggunakan metode on the job training yaitu mengkhusus metode pembimbingan dimana pelatihan diberikan oleh divisi trainer dibimbing tentang selling skill dan peserta menerapkannya di dalam pekerjannya yang langsung. Metode ini sangat efektif dilakukan karena langsung mengetahui bagaimana keterampilan bawahannya. Pelatihan ini dilaksanakan setiap 6 bulan sekali di PT. Arta Sedana Cabang Denpasar.

Training supervisory Skill diberikan kepada sales yang berkompeten menjadi supervisor sales dan yang telah menduduki jabataan supervisor sales. Pelaksanaan pelatihan ini dilakukan satu tahun sekali biasanya 09 Maret yang bertepatan dengan hari ulang tahun PT. Arta Sedana Singaraja. Tugas dan peran seorang supervisor di PT. Arta Sedana sangatlah penting selain dituntut untuk dapat menyelesaikan tugas-tugas yang bersifat teknis yang dibebankan, supervisor juga dituntut untuk dapat memotivasi, mengarahkan dan membimbing bawahannya. Tujuan Training supervisory skill yaitu memahami fungsi-fungsi utama supervisor, membekali kemampuan dalam menciptakan lingkungan kerja yang produkti, meningkatkan keahlian dalam berkomunikasi. Metode pelatihan dari training supervisory skill yaitu presentasi dan diskusi. PT. Arta Sedana rela mengeluarkan dana yang tidak sedikit demi tercapainya pelaksanaan pelatihan tersebut karena perusahaan yakin apabila karyawan telah dilatih maka mereka akan memiliki kemampuan dan keterampilan lebih baik, sehingga mereka mampu bekerja lebih efektif dan efisien, dan akhirnya karyawan tersebut mendapat penilaian kerja yang baik pula dalam meningkatkan kinerjanya.

Sistem pengembangan sumber daya manusia yang kedua yaitu promosi jabatan yang telah dilaksanakan di PT Arta Sedana Singaraja yaitu promosi jabatan sales menjadi supervisor sales. Promosi jabatan ini sangat diperlukan karena dengan adanya promosi jabatan ini akan mendorong karyawan untuk lebih baik dan lebih semangat dalam melakukan suatu pekerjaan dalam lingkungan organisasi atau perusahaannya. Adanya promosi jabatan akan membuat karyawan merasa dihargai, diperhatikan, dibutuhkan dan 
diakui kemampuan kerjanya oleh perusahaan. Pemberian jabatan yang lebih tinggi ini mengacu pada lamanya waktu bekerja sebagai sales yaitu minimal 3 tahun, mencapai target selama 12 bulan berturut-turut dan memiliki kinerja bagus. Pihak manajemen perusahaan PT. Arta Sedana Singaraja percaya jika promosi jabatan dilakukan dengan maksimal, tetap sasaran dan adil, karyawan akan semakin termotivasi dalam melaksanakan pekerjaanya maka dari itu kinerja yang dihasilkan akan semakin tinggi.

Sistem pengembangan sumber daya manusia yang ketiga yaitu fasilitas sales force automation (SFA). Fasilitas berupa handphone kepada sales yang berisikan aplikasi sales force automation (SFA) merupakan sistem automatisasi tugas seorang sales sehingga dapat meningkatkan kinerja dan penjualan agar lebih efisien, efektif dan terkontrol. SFA ini akan terhubung dengan pelanggan yang akan secara otomatis mencatat setiap transaksi penjualan produk. Tentu dengan adanya SFA ini akan mempermudah dan mempercepat pekerjaan sales dalam melayani pelanggan. Kelebihan SFA ini yaitu data transaksi yang dilakukan akan lebih akurat, meningkatkan kepuasaan pelanggan. Pihak manajemen perusahaan PT. Arta Sedana Singaraja berharap dengan adanya SFA ini para sales mampu bekerja secara efektif dan efisien yang pada akhirnya akan mamppu meningkatkan kinerjanya.

Sistem pengembangan sumber daya manusia yang ke empat yaitu isentif yang diberikan di PT. Arta Sedana Singaraja merupakan penghasilan tambahan yang diberikan perusahaan kepada para karyawan yang melampaui target yang telah ditetapkan. Pemberian isentif didasari atas target yang telah melampaui standar yang ditentukan dan jam kerja yang lebih lama dari jam kerja, serta bekerja pada saat hari libur nasional. Fungsi utama dari pemberian isentif adalah untuk memberikan tanggung jawab dan dorongan kepada karyawan. Tujuan utama dari pemberian isentif meningkatkan kinerja karyawan. Jenis isentif yang berikan perusahaan hanya finansial isentif yang diberikan kepada karyawan melalui penambahan dalam gaji pokok yang telah diberikan perusahaan. Pihak perusahaan berharap dengan adanya penerapan isentif akan meningkatkan semangat karyawan untuk mencapai target yang telah ditetapkan sehingga akan diikuti pula dengan hasil kinerja yang baik

\section{Analisis Linier Sederhana}

Berikut merupakan hasil analisis regresi linier sederhana pada pengaruh sistem pengembangan sumber daya manusia $(X)$ terhadap kinerja karyawan $(Y)$ di PT. Arta Sedana Singaraja.

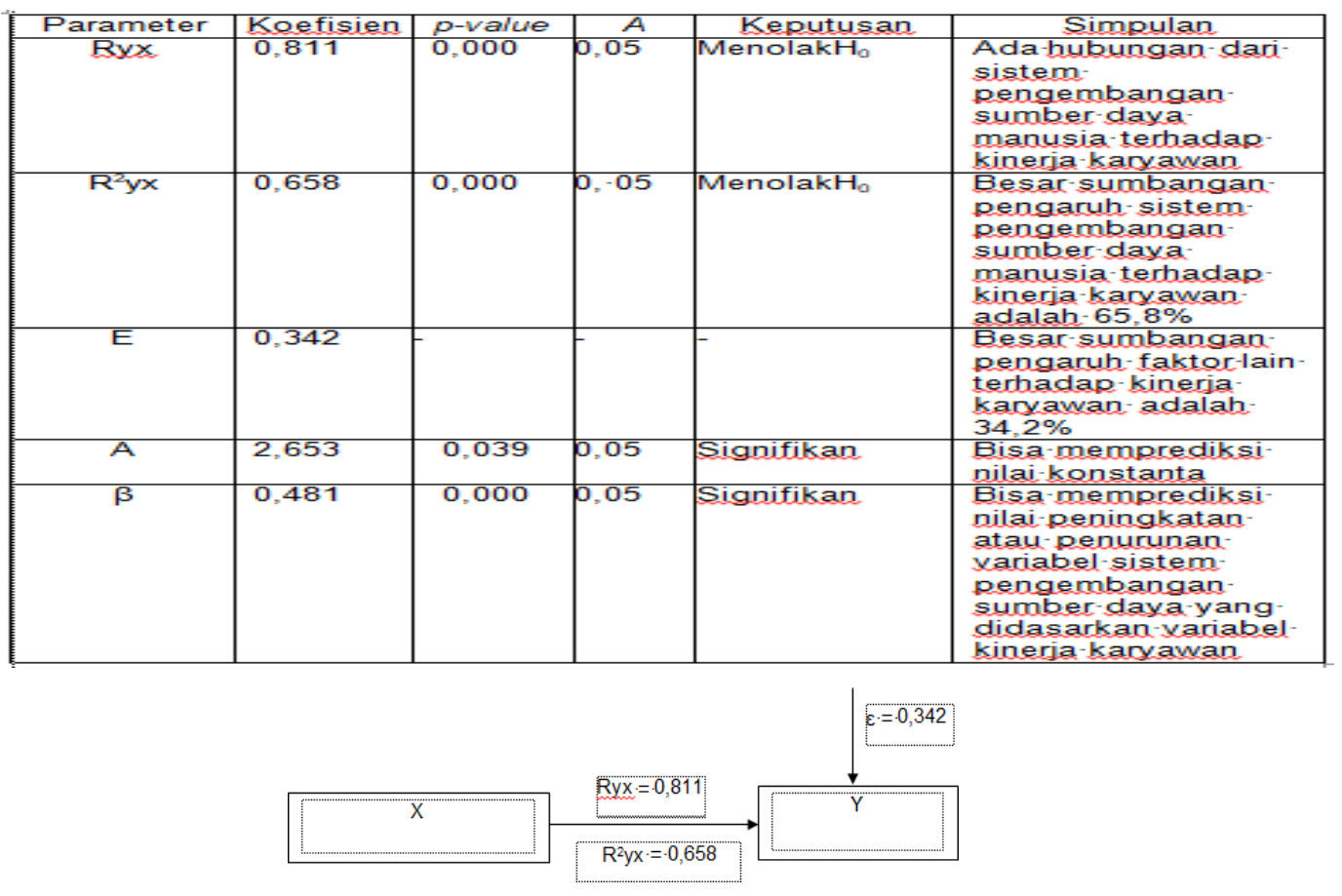

Prospek: Jurnal Manajemen dan Bisnis | 106 
Berdasarkan Gambar 2 dapat diinterpretasikan hubungan antar variabel sebagai berikut.

1. Ryx menunjukkan ada hubungan dari sistem pengembangan sumber daya manusia terhadap kinerja karyawan sebesar 0,658 atau $65,8 \%$.

2. $R^{2} y x$ menunjukkan besar sumbangan pengaruh sistem pengembangan sumber daya manusia terhadap kinerja karyawan adalah $81,1 \%$.

3. Parameter $\varepsilon$ menunjukkan besar sumbangan pengaruh faktor lain terhadap kinerja karyawan adalah $34,2 \%$

Data pada Gambar 2 menunjukan bahwa sistem pengembangan sumber daya manusia berpengaruh secara positif terhadap kinerja karyawan di PT. Arta Sedana Singaraja. Hal tersebut ditunjukkan dengan $p$-value $\operatorname{Ryx}=0,000<\alpha=0,05$. Besar sumbangan pengaruh sistem pengembangan sumber daya manusia terhadap kinerja karyawan adalah 0,658 . Hasil tersebut menunjukkan bahwa sebesar $65,8 \%$ kinerja karyawan dipengaruhi oleh variabel sistem pengembangan sumber daya manusia, sedangkan pengaruh dari variabel lain sebesar $34,2 \%$. Berdasarkan hasil analisis regresi linier diatas jadi kesimpulan dalam penelitian ini bahwa terdapat pengaruh positif dan signifikan sistem pengembangan sumber daya manusia terhadap kinerja karyawan di PT. Arta Sedana Singaraja.

\section{Pembahasan \\ Sistem Pengembangan Sumber Daya Manusia di PT. Arta Sedana Singaraja}

Berdasarkan hasil penelitian yang dipaparkan bahwa pelaksanakan sistem pengembangan sumber daya manusia secara maksimal akan dapat meningkatkan kinerja karyawan sehingga tujuan atau harapan perusahaan dapat tercapai. Adapun sistem pengembangan sumber daya manusia yang dimaksud dapat meningkatkan kinerja adalah sebagai berikut.

Salah satu cara bagi PT. Arta Sedana Singaraja untuk meningkatkan kinerja karyawannya yaitu dengan mengasah kemampuan dari para karyawannya melalui pelatihan. Pernyataan tersebut didukung oleh Ivancevich (2008: 45) menyatakan pelatihan sebagai proses sistematis untuk mengubah prilaku kerja seorang/sekelompok pegawai dalam usaha meningkatkan kinerja. Pihak manajemen PT. Arta Sedana rela mengeluarkan dana yang tidak sedikit demi tercapainya pelaksanaan pelatihan tersebut karena perusahaan yakin apabila karyawan telah dilatih maka mereka akan memiliki kemampuan dan keterampilan lebih baik, sehingga mereka mampu bekerja lebih efektif dan efisien, dan akhirnya karyawan tersebut mendapat penilaian kerja yang baik pula dalam meningkatkan kinerjanya. Sejalan dengan teori Gomez (2007), menyatakan pelatihan sebagai proses membekali para karyawan dengan keterampilan khusus atau membantu mereka memperbaiki kelemahan dalam kinerja.

Diharapkan dengan adanya pelatihan dapat meningkatkan kinerja dari karyawan dan lebih memahami deskripsi pekerjaannya sehingga kinerja dari masing-masing karyawan yang mendapatkan pelatihan dapat bekerja lebih optimal untuk memajukan perusahaan. Pelatihan mampu meningkatkan kinerja karyawan seperti hasil penelitian yang dilakukan oleh Denny (2014), pengaruh pelatihan kerja terhadap kinerja karyawan pada PT. Pos Indonesia Cabang Kediri dengan hasil penelitian yang menyatakan bahwa pelatihan kerja berpengaruh signifikan terhadap kinerja karyawan. Dari pelatihan kerja tersebut akan berdampak pada peningkatan kinerja karyawan yang secara langsung mempengaruhi kinerja perusahaan.

Promosi jabatan merupakan sistem pengembangan SDM di PT. Arta Sedana yang mampu mempengaruhi kinerja karyawannya.PT. Arta Sedana Singaraja percaya jika promosi jabatan dilakukan dengan maksimal, tetap sasaran dan adil, karyawan akan semakin termotivasi dalam melaksanakan pekerjaanya maka dari itu kinerja yang dihasilkan akan semakin tinggi.Sejalan dengan pernyataan dari Handoko (2004) menjelaskan bahwa promosi jabatan akan memberikan motivasi yang positif terhadap karyawan dalam bekerja yang berdampak terhadap kinerja karyawan meningkat.Kajian 
empirik yang turut mendukung promosi jabatan bagian dari sistem pengembangan SDM mempengaruhi kinerja karyawan seperti hasil penelitian yang dilakukan oleh Suharni (2017) yaitu terdapat pengaruh positif dan signifikan promosi jabatan terhadap kinerja karyawan di PT. Garuda Metalindo.

Fasilitas memadai yang diperoleh karyawan PT. Arta Sedana Singarajaakan mampu melaksanakan pekerjaan secara efektif dan efisien yang pada akhirnya akan mamppu meningkatkan kinerjanya. Hal ini dipertegas oleh Lupiyaodi (2006) yang menyatakan bahwa semakin baik fasilitas yang digunakan semakin baik program yang dijalankan sehinggameningkatkan kinerjanya.Kajian empirik yang turut mendukung fasilitas bagian dari sistem pengembangan SDM mempengaruhi kinerja karyawan seperti hasil penelitian yang dilakukan oleh Nurul (2019) yaitu terdapat pengaruh positif dan signifikan fasilitas terhadap kinerja pegawai pada Bagian Sekretariat Badan Pengelolaan Keuangn Daerah Provinsi Sulawesi Selatan.

PT. Arta Sedana Singaraja berharap dengan adanya penerapan isentif akan meningkatkan semangat karyawan untuk mencapai target yang telah ditetapkan sehingga akan diikuti pula dengan hasil kinerja yang baik. Hal ini sejalan dengan Wibowo (2012) menyatakan bahwa isentif mempunyai hubungan kinerja karyawan karena setiap pekerjaan yang telah memberikan kinerja terbaiknya pasti mengharapkan imbalan disamping gaji pokok sebagai tambahan berupa isentif atas kinerja yang telah diberikannya terhadap perusahaan. Kajian empirik yang turut mendukung pemberian isentif bagian dari sistem pengembangan SDM mempengaruhi kinerja karyawan seperti hasil penelitian yang dilakukan oleh Maziah (2016) yaitu terdapat pengaruh positif dan signifikan isentif terhadap kinerja karyawan pada PT. BNI Syariah Makassar.

\section{Pengaruh Sistem Pengembangan Sumber Daya Manusia Terhadap Kinerja Karyawan di PT. Arta Sedana Singaraja}

Berdasarkan penelitian yang telah dilakukan, maka diperoleh temuan bahwa variabel sistem pengembangan sumber daya manusia berpengaruh signifikan terhadap kinerja karyawan di PT. Arta Sedana Singaraja. Hasil penelitian ini mendukung teori yang disampaikan oleh Robert dan Jackson (2002) bahwa jika karyawan mengambil lebih banyak aktivitas pengembangan sumber daya manusia, maka kinerjanya akan lebih tinggi lagi. Menurut Mathis dan Jackson (2010), salah satu faktor yang mempengaruhi kinerja adalah sistem pengembangan sumber daya manusia. Pendapat lainnya menurut Rowley dan Jackson (2012) bahwa sistem pengembangan sumber daya manusia adalah sebuah proses yang dilakukan untuk mengembangkan pengetahuan, keahlian, dan kemampuan pekerja, demikian juga dengan kompetensi-kompetensi yang dikembangkan melalui pelatihan dan pengembangan untuk kepentingan peningkatan kinerja. Pengembangan sumber daya manusia secara maksimal akan dapat meningkatkan kinerja karyawan sehingga tujuan atau harapan perusahaan dapat tercapai.

Kajian empirik yang turut mendukung temuan penelitian ini adalah hasil penelitian yang dilakukan oleh Dinny (2018), yang meneliti tentang pengaruh sistem pengembangan sumber daya manusia terhadap kinerja karyawan PT Indofood Cbp Sukses Makmur Tbk Bitung. Hasil penelitiannya menyatakan bahwa sistem pengembangan sumber daya manusia berpengaruh positif dan signifikan terhadap kinerja, sehingga jika sistem pengembangan sumber manusia dilakukan dengan maksimal maka kinerja dari karyawan akan mengalami peningkatan.

\section{SIMPULAN DAN SARAN \\ Simpulan}

Berdasarkan hasil dan pembahasan yang telah dilakukan, maka dapat ditarik beberapa simpulan sebagai berikut.

Berdasarkan hasil pengujian statistik dan hipotesis serta pembahasan yang telah dilakukan dapat ditarik simpulan sebagai berikut. (1) Pelatihan terhadap karyawan baru yang akan menduduki jabatan sales yaitu Pelatihan selling skill Pelatihan selling skill bertujuan 
untuk membekali para sales tentang pengetahuan dasar dan teknik melakukan penjualan terhadap konsumen; Promosi jabatan yang telah dilaksanakan di PT Arta Sedana Singaraja yaitu promosi jabatan sales menjadi supervisor sales. Adanya promosi jabatan akan membuat karyawan merasa dihargai, diperhatikan, dibutuhkan dan diakui kemampuan kerjanya oleh perusahaan. Sistem pengembangan sumber daya manusia yang dilaksanakan PT. Arta Sedana Singaraja yaitu telah mampu memberikan fasilitas berupa handphone kepada sales yang memiliki aplikasi sales force automation (SFA).; Isentif yang diberikan di PT. Arta Sedana Singaraja merupakan penghasilan tambahan yang diberikan perusahaan kepada para karyawan yang melampaui target yang telah ditetapkan. (2) istem pengembangan sumber daya manusia berpengaruh positif dan signifikan terhadap kinerja karyawan di PT. Arta Sedana Singaraja. Hal ini berarti sistem pengembangan sumber daya manusia memiliki peran yang penting dalam peningkatan kinerja karyawan. Sistem pengembangan sumber daya manusia yang baik dapat meningkatkan kinerja karyawan.

\section{Saran}

Berdasarkan hasil, pembahasan, dan simpulan, maka dapat diajukan beberapa saran sebagai berikut. (1) Bagi pihak manajemen PT. Arta Sedana Singaraja agar lebih memperhatikan sistem pengembangan sumber daya manusia dalam upaya untuk meningkatkan kinerja karyawan, karena penelitian ini membuktikan bahwa sistem pengembangan sumber daya manusia dapat mempengaruhi kinerja karyawan. Pihak manajemen harus memberikan pelatihan dan pengembangan terhadap karyawan agar karyawan memahami tugas yang harus mereka selesaikan. Hal tersebut karena sistem pengembangan sumber daya manusia bertujuan untuk merubah sumber daya manusia yang dimiliki organisasi, dari suatu keadaan ke keadaan lain yang lebih baik melalui pendidikan jangka panjang dan pengalaman belajar dalam mempersiapkan karyawan untuk tanggung jawab di masa mendatang. Sistem pengembangan SDM yang berjalan baik akan mendukung tercapainya standar kinerja karyawan yang telah ditetapkan (2) Bagi peneliti selanjutnya yang tertarik untuk mengkaji aspek yang serupa yaitu sistem pengembangan sumber daya manusia dan kinerja karyawan diharapkan untuk mengembangkan penelitian ini dengan menggunakan populasi dan sampel yang lebih luas agar hasil penelitian lebih teruji keandalannya. Disamping itu, diharapkan untuk menguji variable lain yang diduga kuat dapat mempengaruhi kinerja karyawan.

\section{DAFTAR PUSTAKA}

Arikunto, S. (2010).Prosedur Penelitian Suatu Pendekatan Praktek. Jakarta: PT. Rineka Cipta.

Mangkunegara. (2015). Manajemen Sumber Daya Manusia Perusahaan. Bandung: Rosda.

(2011). Perencanaan dan Pengembangan Sumber Daya Manusia. Bandung: Refika Aditama

Ayu Irmayani, Nita. 2018. Pengaruh Pendidikan terhadap Kinerja Karyawan Pada Dinas Pemuda dan Olahraga Provinsi Jawa Barat. Jurnal Ekonomi Bisnis Vol 5 No 1

Busono, Agung.2016 Pengaruh Sistem Pelatihan dan Pengembangan Karyawan Terhadap Kinerja Karyawan PT. Persada Sawit Mas. Jurnal Fakultas Ekonomi dan Bisnis Palembang Vol 1 No1

Chris Rowley \& Keith Jackson. 2012. Manajemen Sumber Daya Manusia The Key Concepts, Cetakan Kesatu. Jakarta: PT Rajagrafindo Persada.

Dinny.2018. Pengaruh Sistem Pengembangan Sumber Daya Manusia Terhadap Kinerja Karyawan PT. Indofood Cbp Sukses Makmur Tbk Bitung. Jurnal EMBA Vol 6 No 4

Elnaga, Amir. 2013 The Effect of Training on Employee Performance. European Journal of Business and Management ISSN 2222-1905 ISSN 2222-2839

Gomez, Mejia,dkk.2007. Managing Human Reseorces. Ed. Upper Saddle River, New Jerssey : Prentice Hall.

Giovani, Chiristoper.2014. Pengaruh Pengembangan Sumber Daya Manusia Terhadap Kinerja Karyawan Pada PT. PLN Cabang Binjai. Jurnal Administrasi P-ISSN-2549- 
9165 e-ISSN-2580-2011

Gorda, I Gusti Ngurah. 2004. Manajemen Sumber Daya Manusia. Edisi Revisi. Denpasar. Astabrata Bali.

Hasibuan. 2007. Manajemen Sumber Daya Manusia, Edisi Revisi, Bumi Aksara. Jakarta 2011. Manajemen Sumber Daya Manusia. Jakarta: PT. Bumi Aksara 2014. Manajemen Sumber Daya Manusia. Bandung: Bumi Aksara.

Henry Simamora.2010.Manajemen Sumber Daya Manusia.Jakarta:Gramedia.

Herman Sofyandi.2008.Manajemen Sumber Daya Manusia. Edisi Pertama.Yogyakarta: Penerbit Graha IImu.

Handoko, T. Hani.2010. Manajemen Personalia dan Sumber Daya Manusia. Yogyakarta

Ivancvich, John. M. dkk. 2008. Perilaku dan Managemen Organisasi. Jilid 1 dan 2. Jakarta : Erlangga

Lupiyoadi, Handani. 2006. Manajemen Pemasaran Jasa. Salemba Empat:Jakarta

Mangkuprawira, Sjafri. 2011. Manajemen Sumber Daya Manusia Strategik (edisi kedua). Ghalia Indonesia: Bogor.

Mathis Robert, Jackson John. 2010. Human Resources Mangement edisi 10. Jakarta: Salemba Empat.

Maziah.2016.Pengaruh Pemberian Isentif Terhadap Kinerja Karyawan Pada PT. BNI Syariah Makassar. Jurnal Fakultas Ekonomi dan Bisnis. Makassar Vol 12 No 1

Notoatmodjo, Soekidjo. 2009. Pengembangan Sumber Daya Manusia. Jakarta: Rineka Cipta.

Rahayu, Suharni.2017. Pengaruh Promosi Jabatan Terhadap Kinerja Karyawan Pada PT. Garuda Metalindo. Jurnal Kreatif Pemasaran, Sumber Daya Manusia, dan Keuangan Universitas Pamulang Vol 5 No1

Robbins, P. Stephen. (2006). Perilaku Organisasi.Jakarta: Salemba Empat.

Santoso, Singgih. 2012 Panduan Lengkap SPSS Versi 20. Jakarta: PT Elex Media Komputindo

Sedarmayanti.2009.Sumber Daya Manusia dan Produktivitas Kerja.Bandung: CV. Mandar Maju.

Siagian, Sondang P. 2012. Manajemen Sumber Daya Manusia. Jakarta: Bumi Aksara.

Sugiyono. (2014). Metode Penelitian Pendidikan Pendekatan Kuantitatif, Kualitatif, dan R\&D. Bandung: Alfabeta.

Sutrisno, Edy. 2014. Manajemen Sumber Daya Manusia. Jakarta: Kencana.

Triasmoko, Denny.2014. Pengaruh Pelatihan Kerja Terhadap Kinerja Karyawanpada PT. Pos Indonesia (Persero) Cabang Kota Kediri. Jurnal Administrasi Bisnis Universitas Brawijaya Malang Vol 12 No 1

Wibowo . (2014) . Manajemen Kinerja. Edisi Keempat . Jakarta : Rajawali Pers 